Alexander-Arthur Niedziolka

\title{
From Troy to the New World: Thomas Morton's New English Canaan and the Question of Indian Discourse
}

\section{Introduction}

"It is always possible that one might speak the truth in the space of a wild exteriority, but one is 'in the true' only by obeying the rules of a discursive 'policing' which one has to reactivate in each of one's discourses" (Foucault 61). This Foucauldian quote nicely sums up the dilemma of analyzing Thomas Morton's New English Canaan: ${ }^{1}$ most of what Morton says, albeit in a highly heterogeneous and complex way, sounds "true" to modern day readers. However, as Foucault has correctly observed, not even a "wild exteriority," be it a discursive or a regional one like early colonial America, provides the possibility to speak freely. Due to Puritan predominance in New England, Morton's discourses have been characterized mainly in comparison to the Puritans' political, social, and, above all, religious ideas. The result is a bipartite critical reception of Morton: one side sees him as a

1 In the following referred to as NEC. 
licentious libertine, as a direct attack on early American core values as represented by the Puritans; the other side tries to be more sympathetic and portrays Morton as the more humane counterpart to Bradford's and Winthrop's followers.

This work will attempt to overcome such narrow approaches to NEC. To do so, one of Morton's most fascinating and complex discourses will be analyzed, his Indian discourse. ${ }^{2}$ First, a "genealogical" (Foucault 70) analysis will be done so as to reconstruct how Morton's Indian discourse emerged. Here, the historical situations in Old and New England will be presented, with a special emphasis on similarities between both cultural spheres. Then, several English travel accounts which were published prior to Morton's voyages will be scrutinized and their influence upon Morton's Indian discourse discussed. Second, a "critical" (Foucault 70) analysis will be done in the third and fourth part of this work. It will be guided by two major questions: How does Morton talk about the Indians? To what ends does he employ such talk? It will be tried to show that Morton took existing similarities between Old and New England, enlarged on them, and thus tried to depict Native Americans and the English as two similar peoples with the same cultural origins and ancestry. By doing so, Morton sought to create a unique strategy of appropriating the land: by reason of the shared origin, only the English and especially Anglican gentlemen like Morton are fit and legally allowed to colonize New England.

\section{Genealogical Analysis}

In many ways, it is remarkable that Thomas Morton and his New English Canaan form part of the contemporary US-American literary canon. This is so because even a superficial analysis of his work reveals that Morton is an almost prototypical English gentleman of his time, "a classical humanist, and a follower of the Church of England's via media" (Galinsky 33). Thus, in order to understand the forming of Morton's Indian discourse, it makes sense to begin this work with a somewhat brief historiographical analysis of England in the late $16^{\text {th }}$ and early $17^{\text {th }}$ century. Special emphasis will be put on political practices and world views. Subsequently, with the help of historiographical sources, a similar overview of Native American life in New England will be given. Both analyses will show that there were certain similarities between Old and New England that served Morton as an important basis for his Indian discourse. In a third step, actual encounters between English voyagers and Native American tribes which took place before Mor-

2 When the word "discourse" is used in this work, it specifically refers to the Foucauldian understanding of the term. Thus, discourse is understood "as a violence which we do to things, or in any case as a practice which we impose on them; and it is in this practice that the events of discourse find the principle of their regularity" (Foucault 67). Moreover, discourses will be treated as "discontinuous practices, which cross each other, are sometimes juxtaposed with one another, but can just as well exclude or be unaware of each other" (Foucault 67). 
ton's first arrival in New England will be analyzed, with a close look at their concepts of intercultural contact.

\subsection{Elizabethan and Early Stuart England}

When Elizabeth I ascended the English throne in 1558, the country faced a deep religious crisis manifesting itself in the ongoing conflicts between Catholics, Anglicans, and Protestants. Besides these internal quarrels, there were external problems as well, in particular with France, Scotland, and Spain. In this situation, Elizabeth tried to draw up a political program which should "find a religious settlement acceptable to the overwhelming majority of her subjects and [that should] keep England out of war" (Viault 118).

Yet, the search for such a "religious settlement" was problematic. Henry VIII had broken with the Pope and created the Anglican Church; Edward VI had installed Protestant reforms, whereas his successor Mary returned to a pure Catholic doctrine. Since both Edward's and Mary's reigns were relatively short, they failed to achieve national religious unity. The result was a country that "remained prone to factionalism and disorder" (Manning, "Elizabeth" 40). To fight these developments, Elizabeth tried to reverse Mary's Catholic legacy by enforcing the Act of Supremacy and the Act of Uniformity, both in 1559. The former established Elizabeth as the "supreme governor" of the Church of England, whereas the latter introduced a modified 1552 Book of Common Prayer and "decreed its use in the country's churches" (Viault 119). Although both acts look like straight antiCatholic proceedings, Elizabeth did not pursue an entirely Protestant course either. In reality, the program of the Anglican Church was a curious mixture of Protestant and Catholic rituals. The 1559 Book of Common Prayer, for example, was largely based on the one issued under Edward VI and thus chiefly Protestant in character. Nevertheless, many Catholic liturgical practices were retained, e.g. "using the sign of the cross" or "requiring clergymen to wear the surplice when ministering the sacraments" (Manning, "Elizabeth" 44). Therefore, it can be said that Elizabeth's religious policy fostered a certain form of syncretism by consciously intermingling Protestant and Catholic doctrines. Naturally, radical Catholics as well as Protestants were not satisfied with these tendencies. However, the vast majority did not care too much, went to parish church every Sunday, and simply "conformed" (Picard 275). Especially villagers and poor, illiterate people rejected Protestantism, for it relied too much on educated preaching and the study of the Bible. Most of these people adhered to the "oral traditions and symbolic ritualism of medieval England" (Morgan 303). This is something one must take into account when discussing Morton's raising of a maypole. With this ancient English fertility ritual and the revels, Morton did not represent the ideas of the social elite but the convictions of the majority of the English population. 
On the whole, the attempt of a comprehensive religious settlement shows a crucial idea of Elizabethan England's way of doing politics, the idea of a "via media" (Cannon, "Elizabeth" 340). With regard to the religious question, it tried to reinforce Protestantism without directly fighting Catholicism. Yet, as Lee has shown, the notion of the via media as a "consciously imposed" policy is erroneous (42). Rather, it was "a delicate operation to balance a variety of forces" (Sheils qtd. in Lee 42). In other words, the via media was an extremely pragmatic, yet cautious way of doing politics.

The religious question, however, did not only have domestic but also foreign policy ramifications, most notably the conflicts with Catholic France and Spain during Elizabeth's reign. Yet, even in these disputes, the queen showed no fixed "ideology" but once again a strong political "pragmatism" (Lee 93). This attitude is pointedly exemplified in the conflict with Spain. Obviously, this struggle mirrored the ubiquitous fight between Protestantism and Catholicism in Europe. Nevertheless, there were political and commercial reasons for this conflict that played an equally important role. The Protestant Dutch were revolting against Spanish rule and Elizabeth supported this uprising by sending troops in 1585. Thus, she hoped to establish a "strong Dutch bulwark against the tide of Spanish aggression" (Andrews 197). Furthermore, the queen was interested in keeping the Netherlands open for English trade. The factor which finally led to the outbreak of war was England's growing interest in the New World trade. By investing in two of the voyages undertaken by John Hawkins and by supporting Sir Francis Drake, Elizabeth directly tried "to break into the Spanish monopoly in the Caribbean" (Lee 95) and America. Needless to say, this aroused the opposition of Spain's Philip II. Overall, given the gradual decline of English economy in the $16^{\text {th }}$ century combined with a substantial growth in population, it seems probable that the economic and political reasons for the war were far more pressing than the religious ones. This strong focus on free trade possibilities and a pronounced political pragmatism are features that will eventually play a major role in Morton's New England agendas, too.

In 1603, the ascension of James I to the English throne marked a clear turning point in English politics. "The very reverse of Queen Elizabeth" (Morgan 350), he was a staunch monarch and convinced of his unfettered royal authority. Even so, he acknowledged the fact that he could only govern together with Parliament and that his legal decisions were subject to "judicial review" (Morgan 351). Moreover, he constantly tried to avoid direct confrontations. In this context, it is indicative that immediately after the beginning of his reign he signed a truce and ended the war with Spain. This search for harmony can also be found in his religious policy. Although his Protestantism was "unquestionable" (Lockyer, "James" 528), he showed a good deal of tolerance towards Catholics. Consequently, he also pursued a via media in his religious policy, albeit for different reasons than his precursor. With regard to Morton's doings in the New World, the reign of James I was im- 
portant for two reasons: the continuation of the religious settlement and James's emphasis on law and its strict enforcement.

The last era which is of significance for an analysis of Morton is the reign of Charles I from 1625 to 1649. Whereas his peaceful forerunner had avoided confrontations, Charles engaged in wars against Spain and France (Morgan 354). In 1629, he broke with Parliament because the delegates were not willing to pay for the king's costly and aggressive foreign policy. Furthermore, Charles irritated Parliament with his religious agenda. Above all, it was his support of the Arminians and of Archbishop William Laud that scandalized the public. The Arminians did not believe in the Calvinist concept of predestination (which had been adopted by the Church of England) and adhered to numerous rituals that closely resembled Catholic ones. In general, this movement consisted of high churchmen like Charles, whereas the "members of Parliament were predominantly low church" (Lockyer, "Charles" 190). Both factors led to a complete break between king and Parliament. As a result, Charles governed the country without Parliament from 1629 to 1640 . The situation was further aggravated by the 1633 appointment of William Laud as archbishop. This growing religious alienation between the king and his subjects was one of the major reasons for the outbreak of the civil war in 1642.

To summarize, the reigns of Elizabeth and James were important for Morton's formation. The notion of a via media was omnipresent, political pragmatism played a significant role, and England's trading rights, especially in the New World, were brought into public focus. All these aspects left their mark on Morton's character and world view as expressed in NEC. Charles's reign provided the immediate background for Morton's voyages to New England and the subsequent legal actions against the Puritans. Here, the turning to high church religious doctrine, embodied in the person of William Laud, had a momentous impact on the composition of NEC and explains the weight Morton attaches to Anglicanism in his argumentation.

\subsection{Native American New England}

Discussing Native American cultures in a short manner is a rather difficult and risky thing to do. First, due to the lack of authentic Indian documents, it is impossible to reliably reconstruct cultural and social Indian practices before and during the early colonial period. Second, one runs the risk of suggesting the existence of a generic Native American, an error committed by many colonial writers. In the following, only the tribes most likely to be in contact with Morton will be discussed. Given the location of Ma-re Mount, it seems very probable that those were the Massachusetts, the Narragansetts, and the Wampanoags. ${ }^{3}$ A focus on

3 Sometimes also referred to as Pokanoket (Manning, "Wampanoag" 661). 
only these three neighboring tribes makes it easier to determine common features and avoid the risk of artificially yoking together highly diverse cultural communities.

Nevertheless, there were two characteristics which not only the Massachusetts, Narragansetts and Wampanoags, but, in fact, nearly all Native American cultures shared. First, Indian societies were structured around "multigenerational families" rather than around individuals (Boyer 2). Second, Native Americans believed in a complex system of reciprocity in order to regulate relations between different tribes (Boyer 2). As Salisbury has pointed out, this notion of reciprocity can be seen as the most defining Indian "ethos" and was not only confined to the social or political sphere, but played the predominant role in natural and religious practices as well (Manitou 10).

Focusing on the three Southern New England Indian cultures, one can safely state that all of them pursued a rather traditional way of life upon European arrival. Agriculture was only a recent development; hence, hunting and gathering still played a crucial role. This also explains the semisedentary life of all three tribes. Their villages were no "fixed geographical units" (Cronon 38), but highly mobile communities. Thus, New England Indians could flexibly react to seasonally changing food availability. Looking at this practice, one can see that these native tribes understood New England as an ecosystem of "periodicity" (Cronon 37) and adapted their way of life accordingly. ${ }^{4}$

This notion of life, however, was not only a mere continuation of traditional practices or a reaction to the ecological situation but also had "important social and cultural implications by providing the basis for a rudimentary but regular annual cycle" (Salisbury, Manitou 10). The Narragansetts' year, for instance, was marked by "a series of seasonal moves, and by festivals, games, and rituals" (Bragdon, "Narragansett" 417). In general, these Indian rituals fulfilled several religious and communal functions and thus were very similar to medieval traditions still practiced in England at that time (Slotkin 57-8). ${ }^{5}$ In addition, the already mentioned adherence to oral traditions by much of the $16^{\text {th }} / 17^{\text {th }}$ century English population can also be found in (pre-)colonial Native American cultures. There, the spoken word was designed "to preserve important cultural information" (Franklin, "Literature" 6) and rituals were used to pass on knowledge.

In this context, the Native American notion of trade becomes important as well. On the one hand, Indians traded in order to profit economically. Thus, besides hunting and gathering for subsistence, New England Indians engaged in "local and long-distance" trade to acquire goods that were not available in their

4 Morton himself compared this behavior to the customs "of the gentry of Civilized natives" (22). He probably refers to the English upper class and its extensive hunting traditions (Morton 22n81).

5 For the various types and functions of Native American ritual in Southern New England see Bragdon (People 217-30). 
immediate environment (Bragdon, People 91-2). On the other hand, trade was seen as a means to extend the "social, cultural, and spiritual horizons" of each society (Salisbury, "Old World" 452). This implies that Native American tribes constantly exchanged information and thus had no entirely fixed social or cultural system. Instead, they showed a considerable degree of flexibility and could reconcile competing world views by integrating new ideas into existing notions. This compromising was something an Englishman of the time just knew too well from his via media-dominated home country. Taking this idea one step further, one can assume certain "compatibility" (Canup 109) between both cultures and their ways of thinking. The Indians and the English shared a scheme of moderation and adhered to traditional ritualistic practices in order to share knowledge. This partial compatibility explains the ease with which neighboring Indians tribes joined Morton's May Day revels.

A last important feature of New England Indian cultures was the notion of hierarchy. Especially due to the influential topos of the noble savage, there still exists the idea of a highly egalitarian Indian culture. At first glance, the ethos of reciprocity with its deliberate avoidance of extremes seems to support this argument. However, with reference to the three tribes in question, this is an entirely false assumption. In reality, the Massachusetts, Narragansetts, and Wampanoags were highly structured and hierarchical societies. First, all three tribes were organized into "local polit[ies]" known as sachemships (Bragdon, People 140). The Narragansetts, for example, had a very strict social hierarchy: on top was the sachem followed by his advisers; only then came the common people, followed by servants and slaves (Bragdon, "Narragansett" 417). Second, gender roles were clearly distributed. Men were responsible for hunting, warfare, diplomacy, and trade, whereas women had to prepare food, take care of the housing, cultivate the fields, and, most importantly, raise and educate the children (Salisbury, Manitou 39). Both observations allow for the following conclusions: first, the English as well as the New England Indian cultures were highly structured and, consequently, compatible to a certain extent. Second, a social division based on gender was known on both sides of the Atlantic.

To summarize, Native American life in New England was far more complex than most Englishmen of the time assumed. Yet, it showed certain characteristics that resembled English traditions and culture: the reliance on the ethos of reciprocity, an enormous interest in trade, the considerable importance of ritual, and strict social and political hierarchies. Morton consciously used these similarities, integrated them into his Elizabethan notions, and, by doing so, produced an Indian discourse which sought to conflate English and Indian culture. 


\subsection{Indian-English Contact Prior to Morton}

The two preceding paragraphs have established the historical roots of Morton's perception of the Indians. But how did English colonizers prior to Morton or his contemporaries experience Native American life in the New World? And in how far did these observations and interpretations influence the formation of Morton's Indian discourse? These are the two central questions which will be dealt with in this section.

Morton's most influential English forerunners in visiting and attempting to colonize the New World were certainly Sir Walter Raleigh, Thomas Harriot, and John Smith. All three stemmed from the same culture as Morton, yet they provided very different discourses of the New World and Indian life.

Of these three, Raleigh was the one most similar to Morton in character. First, he was a typical Elizabethan gentleman, an adventurous type with a classical education and poetic aspirations. ${ }^{6}$ Second, he undertook repeated voyages to the New World, one in 1584 and another one in 1595. Third, and certainly most significantly, he shared Morton's deep economic interest in America. This can be seen in his well-known work The Discovery of Guiana. There, Raleigh displays in detail the excellent natural resources available in the New World and the advanced state of Native American cultures. Especially the former aspect is very similarly treated by Morton (53-5). Still, even if both authors had a lot in common, their conclusions were very different. This becomes evident in their use of the image of America as a woman: Guiana is depicted as a land that "hath yet her maidenhead" (Raleigh) and thus only waits to be raped by English settlers. In NEC, one initially finds a similar image describing New England as a "fair virgin" (Morton 7). However, Morton further develops this metaphor and finally portrays America as a widow in need of a new husband (139)..$^{7}$ Maybe due to Raleigh's outright failure in Roanoke, Morton departs from a system of violation and replaces it with a scheme of deliberate moderation.

Equally important for an understanding of Morton is Thomas Harriot's A Brief and True Report of the New Found Land of Virginia. Harriot, who worked for Raleigh and wrote said work to promote the 1584 Roanoke expedition, has a very positive and optimistic perception of Native Americans. Just like Morton, he acknowledges the cultural diversity of Indian life, e.g. by noting linguistic differences between the tribes (Harriot 35). Far more consequential, however, is Harriot's notion of the Natives' intellect. In some moments, he manages to leave behind his English preconceptions and to judge the native population according to its own standards: " [] $\mathrm{n}$ their proper manner [...] they seeme very ingenious [and] shewe excellencie of wit" (Harriot 36). In other words, Harriot grants the Indians the

\footnotetext{
6 If one follows Dempsey's argumentation and accepts Devonshire as Morton's most likely place of origin (Morton 5-6), then Raleigh and Morton also had the same local background.

7 The implications of this strategy will be discussed in the fourth part of this work.
} 
status of rational beings that will eventually recognize and accept the superiority of English knowledge and culture (36). This idea is clearly echoed in Morton's ideas for civilizing the Natives. Just like Harriot, he tries to convince Native Americans of the benefits of civility by appealing to their rationality (Morton 36-7). On the whole, Harriot envisions a colonization which is not based on coercion or suppression but on the Indians desire for the English's "friendships \& loue" (Harriot 36). Again, Morton shares his ideas, for he also talks about the Natives' "[l]ove towards the English" (1) as an important prerequisite for non-violent intercultural contact. Thus, both authors were outspoken advocates of "gradualism" in the colonial encounter (Dempsey, "Riddle" 296).

Taking John Smith's Generall Historie of Virginia, New-England, and the Summer Isles from 1624, one also finds interesting parallels to Morton. Both authors share a similar understanding of Indian-English trade. Since Jamestown, as whose military adviser Smith acted, was explicitly founded as a trading colony, it is not surprising that Smith pursues a system of trade without many regulations. This is exemplified in his depiction of a trading agreement between himself and Powhatan: for "two great gunnes, and a gryndstone" the Indian chief would give him the Country of Capahowosick, and for ever esteeme him as his sonne Nantaquoud" (Smith, Historie 151). This little scene encapsulates many characteristics important for an understanding of Morton's eventual Indian policy. First, the significant relation between trade and the Native American concept of the extended family is stressed. A successful trade would make Smith part of Powhatan's family so as to strengthen economic and political ties between the Indians and the English. Second, Smith does not hesitate over trading guns with the Indians, a practice that would eventually cause Morton a lot of trouble with the Puritans. However, Smith and Morton both understood the political value New England Indians attached to guns and acted accordingly. In short, they accepted the $\mathrm{Na}$ tives' notion of reciprocity in trade and thus maintained relatively good relations with them.

An earlier work by Smith, A Description of New England, first published in 1616 and later, with minor changes, included in the Generall Historie, is even more important for an understanding of Morton. What is especially remarkable about this book is the fact that Smith lists various Indian tribes for the different regions of New England. Thus, Smith manages to get away from the idea of a generic Indian and acknowledges Native American cultural diversity. Nevertheless, he is perceptive enough to note that the several New England tribes "differ little in language, fashion, or government" (Smith, Description 328). Keeping in mind the already discussed hierarchical structure of the Wampanoags, Narragansetts, and the Massachusetts, Smith's observation seems justified. Furthermore, his remark about the relative linguistic unity of the tribes is correct as well. In fact, it is assumed that all Eastern Algonquian are derived from a common 'Proto-Eastern Algonquian' language" (Salisbury, Manitou 20). Morton also talks about a single "language of 
Alexander-Arthur Niedziolka

the Natives" (96), but at the same time acknowledges Indian cultural diversity and, although indirectly, makes regional distinctions (24). Furthermore, he is aware of intertribal trade (34-6) and conflict (37-40).

Yet, the most striking resemblance between Smith and Morton is their idea of civilizing New England. Smith uses comparisons to culturally developed nations like France, Italy, Persia, or China to state that their only advantage over New England is that " $\mathrm{t}]$ hey are beautified by the long labour and diligence of industrious people and Art" (Description 333). Hence, only "art" and "industry" are needed in order to raise New England to the level of these nations. Morton uses "art" and "industry" twice in "The Author's Prologue" (7). He employs both words in exactly the same manner, namely as a strategy to improve, i.e. civilize, the land. However, whereas Smith seeks to "equalize" (Description 333) existing kingdoms, Morton tries to create a second Canaan, a biblical place (7).

In general, the three preceding authors were important since their writings reached a large readership; however, with the partial exception of Smith, they did not specifically write about New England. If one wants to get detailed accounts of New England Indian life prior to Morton, one has to turn to some less known authors. There were three expeditions to New England, undertaken by the English in the early seventeenth century, which are relevant for the present discussion: the ones of Bartholomew Gosnold (1602), Martin Pring (1603), and George Waymouth (1605) (Bragdon, People 5).

Gosnold's voyage is preserved in John Brereton's A Briefe and True Relation of the Discoverie of the North Part of Virginia. It was published twice; first in 1602 and later in the fourth volume of Samuel Purchas's bestselling Hakluytus Posthumus, or, Purchas his Pilgrimes from 1625.8 In Brereton's account, one finds many features crucial for an understanding of NEC. First, Brereton constantly compares his group's findings to English commodities, but never without mentioning the superiority of the New World products. So, strawberries are "bigger than [...] in England" (Brereton 332), birds exist "in great plenty" (Brereton 332) and are also "bigger than [...] in England" (Brereton 335), and finally the tobacco is "much better than any I have tasted in England" (Brereton 333). These comparisons culminate in a revealing summary statement: " [] n comparison [...], the most fertil part of al England is (of it selfe) but barren" (Brereton 335). This unparalleled fertility of the soil is a very prominent feature in NEC as well (Morton 3, 12, 54, 92). Second, Brereton provides an interesting account of a successful trade with the Natives (336-7). After sitting together for some time, the Indians give the English a beaver skin. The English accept and signal that they want to "enter league" with the Natives, whereupon the Natives make "signes of joy." However,

8 When describing "Lake Erocoise," Morton provides the following statement: "It is ten years since the first relation of these things came to the ears of the English" (96). Given the probable date of composition of NEC (1635-7), Dempsey considers this an allusion to Purchas's influential work (Morton 96n316). 
before the actual trade starts, both groups eat together and are "merry." In this context, it is important that the English provide the food. It seems as if Morton remembered this scene several years later when he tried to promote his beaver trade through his revels. Just like the Gosnold group, Morton understood that the English had to provide a positive stimulus to achieve stable trade relations. In general, this casual and ritualistic style of doing business was very common in early English travel accounts and often referred to as "faire meanes" (Dempsey, "Glossary" 201).

Only one year after Gosnold, in 1603, Martin Pring undertook a voyage to the coast of New England. His account was also included in Purchas's Pilgrims and closely resembles the one by Brereton. Still, it offers several illuminating observations, especially with regard to the crucial moment of the fist Indian-English encounter. The initial response of the English is "to make a small baricado to keepe diligent watch and ward in" (Pring 347) and thus a reaction of isolation. However, when the English voyagers move freely on the land, the Natives actively try to make contact (Pring 347). After this is successfully done, Pring provides the following observations:

We had a youth in our company that could play upon a Gitterne, in whose homely Music they tooke great delight, and would give him many things, as Tobacco, Tobacco-pipes, Snakes skinnes of sixe foot long, which they use for Girdles, Fawnes skinnes, and such like, and danced twentie in a Ring, and the Gitterne in the middest of them, using many Savage gestures, singing lo, la, lo, la, la, lo [...] (347)

Thus, the initial isolation and cautious approaching is replaced by an unexpected cultural intermixture. "[H]omely music" played on a European instrument is easily integrated into an Indian ritual. This notion of integration is even strengthened by the syntax. The clause "and the Gitterne in the middest of them" is embedded in the lively depiction of a Native American dance. Overall, this is a clear example of the already mentioned Indian flexibility to adapt new ideas into their cultural practices. Yet, for a reader like Morton this scene was certainly not only significant for the mere idea of cultural compatibility between the two peoples, but also for its economic results. In this harmonious scene, the Natives freely give some of their goods to the English, including valuable tobacco. Although this giving away of goods was probably part of the ritual, it showed that shared cultural experiences could facilitate trade relations and further improve the "faire meanes" strategy. All in all, this incident reads like a miniature version of Morton's May Day revels, celebrated 24 years later.

Still, the relation between Pring and the Natives did not remain harmonious. When a group of armed Indians approaches the English "baricado," the voyagers suspect an attack and give warning shots, whereupon the Natives withdraw in a "friendly manner" (Pring 351). Shortly afterwards, the Natives "set fire on the 
Woods" (Pring 351), which is interpreted as a threat to the English. In large part due to Morton's more accurate observations (45-6), it is known today that this was not a hostile act but actually a common procedure among New England Indian tribes in order to clear the land (Cronon 49-50).

Another important English voyage to New England was undertaken by George Waymouth in 1605. It was preserved by James Rosier in his A True Relation of the Voyage of Captaine George Waymouth, 1605, published by Purchas in 1625 as well. This account is vital for the present discussion not only because it is the most detailed and nuanced of the three, but also because Waymouth came from Devon and thus probably shared his origin with Morton.

The first thing that sets Rosier's account apart is the fact that it does not show an exclusively optimistic attitude towards New England from the start. Instead, Rosier describes one of the group's first sightings of land as follows: "Thursday, the 16 of May, we stood in directly with the land, and much marvelled we descried it not [...]" (362). Nevertheless, Waymouth and his companions continue their investigations and the account becomes more and more positive. Rosier notes: "We stayed the longer in this place, not only because of our good Harbour, (which is an excellent comfort) but because every day we did more and more discover the pleasant fruitfulnesse" (366). Here, one has an obvious clash between an "a priori hypothesis" and "a posteriori evidence" (O'Gorman 79). The first glimpse of the New World is to a certain degree disappointing for the Waymouth group because they had erroneous expectations due to earlier travel accounts. Only through their own careful observations they manage to fully grasp the natural wonders of New England. This is an important change in the way of writing about America, for it shows that one has to make a conscious effort so as to understand the richness of the land. It is true that Rosier later also gives in to the demands of promotional literature and praises New England in superlative ways (381-4); yet, the development from a rather negative to an entirely positive perception of the New World renders his promotion more effective than the ones by Brereton and Pring. Furthermore, this strategy prefigures an important epistemological paradigm shift, the emergence of empiricism. Not classical knowledge helped Rosier to understand the land, but the conscious use of his senses. This proto-empiricist approach is also to be found in Morton. Already on the title page he states that his writing is based "upon ten years' knowledge and experiment of the Country" (Morton 1). Moreover, Morton also portrays his positive attitude towards New England as the product of deliberate observation. He goes out into the land, observes and "endeavor[s] to take a survey of the country" (Morton 53). All in all, Morton summarized his and Rosier's tactic to the point in the following, much quoted statement: "The more I looked, the more I liked it" (53). The "liking" is presented as the direct result of the "looking," or, in other words, the use of the senses. The syntactic parallelism further strengthens this effect. 
Sensual experience also provides the basis for Rosier's way of depicting the Indians. He leaves no doubt that his group's only interest in the New World is an economic one (369) and that their chief strategy for achieving this end is to treat the Natives "with as much kindnes as [they] could" (368). After several successful trade experiences with the Indians, Rosier notes that they found "civility [...] in a people where [they] little expected any sparke of humanity" and even talks about "our Salvages" (369-70). However, this positive appraisal does not keep the Waymouth group from kidnapping five Native Americans to bring them back to England. Rosier talks about the necessity of Natives learning the English language so that the English can find out more about Native American culture and society and thus obtain all the information he and his group cannot "by any observation of [themselves] learne in a long time" (388). Hence, by combining sensual experience with linguistic exchange, the Waymouth group tried to maximize its "profits" (393). These "profits" are systematically collected in a catalog at the end of Rosier's Relation and it is worthy of note that besides plants and animals the names of the five abducted Indians are also included in this list (394). Thus, in the end there is a certain reification of Native Americans that qualifies the complaisant depiction before. Still, this implicit strategy of reifying is somewhat necessary because it would be impossible for the English to exploit the Indians if they were characterized as an entirely civilized and humane people. Again, one notes the influence of the via media: Rosier tries to reconcile his sensual experience, which has shown him the New England Indians as a witty and civilized culture, with his prefabricated English ideas and interests. The result is a highly ambivalent depiction of Indian life in New England.

Not surprisingly, Rosier's rendering of the Native American attitude towards the English lacks such complexity. Above all, this becomes evident in his description of the kidnapped Indians' behavior. As Rosier writes, they resist at first, but gradually, due to the "kinde usage" of the English, they become "tractable, loving, and willing by their best meanes to satisfie [the English] in any [they] demand of them" (391). Moreover, Rosier states that he never saw "them angry, but merry" (391). Taking this into consideration, one has the impression that Rosier tried to construct a cultural compatibility between the two peoples that was based upon natural submission and domination. It seems as if he feared that "kinde usage" and peaceful trade relations were not enough to promote the land effectively. So, in the end, he loses some of his respect for the Indians and presents them as a naïve, but good-hearted people.

Morton seems to have learned two important lessons from Rosier's depiction of Native American life. First, as it has already been discussed with regard to Harriot, he adapted the idea of Native American "love" for the English. In fact, Morton uses the same words as Rosier, i.e. "tractable" and "[l]ove" (Morton 1, 8). Second, Morton seems to have internalized the idea of "kinde usage" in order to 
establish harmonious trade relations. Yet, in direct contrast to Rosier, Morton does without reifying and artificially simplifying Native Americans.

To summarize, all texts discussed are vital for a genealogical analysis of Morton's Indian discourse. Due to the lack of information about Morton and his life, it is not sure if he has actually read all of them. Yet, the clear parallels with many of the works suggest that Morton was aware of some of them. In addition, even a superficial reading of NEC shows Morton's affection for books and their profound influence upon his perception of the world. Hence, an extensive examination of possible literary precursors in order to reconstruct the foundations of Morton's Indian discourse seems justified.

\section{Critical Analysis}

Having established the formative features of Morton's Indian discourse, it will now be tried to illustrate how Morton combined and altered them. A close reading of NEC with a special emphasis on language and form will clarify the book's difficult communicative framework as well as Morton's strategies of portraying Native Americans. In a second step, the most consequential part of Morton's Indian discourse will be analyzed, namely his strategy of paralleling Indian and English traditions.

\subsection{Language, Form, and Function}

In order to reliably reconstruct and interpret Morton's Indian discourse, it is essential to have a closer look at the literary features of NEC. As in nearly all literary works, form is content in NEC as well. However, such an analysis seems all the more important in this case, for Morton's book is a kaleidoscope of literary genres, registers, and intertextual allusions. In fact, this highly complex form did not only trouble Morton's contemporary Puritan readers, but even led a distinguished historian like Charles Francis Adams to characterize Morton's writing as "very bad and very dull" and marked by a general "incomprehensibility" (19). In order to be able to fully appreciate Morton's multifaceted treatment of Indian discourse, it will be tried to give a clear outline of the structure and style of NEC and its functions. 


\subsubsection{Paratext}

NEC starts with a title page, followed by two dedications. ${ }^{9}$ The first one is addressed to "the Lords and others of His Majesty's most honorable Privy Council, Commissioners for the Government of all His Majesty's Foreign Provinces" (Morton 2); the second one is directed to the reader (Morton 3). Here, one finds a first clue to the stylistic heterogeneity of NEC. On the one hand, Morton seeks to render his book a legal attack on the Puritan way of doing politics in New England. ${ }^{10}$ On the other hand, he attempts to satisfy the demands of the public. He tries to attract future settlers (those that "are desirous to be made partakers of the blessings of God in that fertile soile") and entertain those that are just "inquisitive after novelties" (Morton 3). Such a complex communicative framework, however, makes successful communication difficult. So, David Read is in many ways right when he calls NEC “a case study of poor communication" (72). Interestingly enough, Morton himself seems to have been aware of the unfeasibility of his project. In the poem "In laudem Authoris," following immediately after the dedication to the reader and written by an anonymous "R.O. Gen.," the difficulties are expressed thus: "So diverse are the opinions of this age, / [...] / That hard his task is, that must please in all: / Example have we from great Caesar's fall" (Morton 4). Albeit the argument is to some extent qualified in the following lines, it is remarkable that Morton included this poem in his book, for it shows that he was conscious of his difficult role as an author.

"In laudem Authoris" is followed by the poems of Sir Christoffer Gardiner and an anonymous "F.C. Armiger," both of which display a pronounced skepticism towards Puritanism. Whereas Gardiner, who had been arrested by the Massachusetts Bay Puritans just like Morton (Dempsey, Morton 263), blatantly criticizes Puritan New England, "F.C." provides a more intricate argument. In his poem, there is a noteworthy play with colonial concepts: "Why, in an air so mild, / Are they [the Puritans] so monstrous grown up, and so wild / That salvages can of themselves espy / Their errors, brand their names with infamy" (Morton 6). The word "wild," understood as an antonym to civilized and implying "savage," "ferocious," and "violent" behavior ("Wild"), suggests that the Puritans lack civility, while the New England Indians show signs of it. With this "paradoxical inversion of orthodox rhetoric" (Franklin, Discoverers 186), the Natives are put into a closer relationship with the implied reader, who would certainly consider himself a

9 The paratextual conception of NEC shows clear references to Smith's Description. Smith attached three dedications and seven introductory poems to his book. Although Barbour states that such "commendatory verses [...] were often prefixed to published works in Smith's days" (1: 295), there are many clear parallels between both books. Like Morton, Smith first addresses the king, then the lords and knights and finally the reader. In his dedication, he uses "ants" and "bees" and compares them to future settlers of New England. Morton employs the same metaphors for describing prospective settlers of the "Zona Temperata" (10), i.e. New England.

10 At the time of publication, Morton was engaged in a quo warranto suit and tried to "get the royal Privy Council to revoke the patent for the Massachusetts Bay Colony" (Cohen 3). 
civilized, or non-"wild" person. To strengthen this effect, Morton repeatedly calls the Puritans a "tribe" $(18,129,160,169)$. Conversely, he never uses "tribe" to refer to Native American societies. By further stating that the Natives are able to detect "infamy" in the Puritans, this argument is even taken a step further. Infamy, defined as an "evil fame or reputation" and a "quality of character of being infamous or of shameful vileness" ("Infamy") is assigned to the Puritans. Consequently, if the Natives are able to spot evilness in other people, they have to have high moral standards.

The following and last introductory poem, "The Author's Prologue," written by Morton himself, gives the reader a lot of information about Morton's ideological background. Clearly, it contains "several of the dominant (indeed, rampant) motifs of early propaganda concerning the New World" (Seelye 172). Yet, Morton does not simply list these stereotypes, but modifies them significantly. The following statement illustrates this idea: "So would our Canaan be, / If well-employed by art and industry, / Whose offspring now shows that her fruitful womb, / Not being enjoyed, is like a glorious tomb" (Morton 7). First, one notes the mentioning of "art" and "industry," both of which were already called for in John Smith, as a prerequisite for the creation of a second Canaan. Second, with regard to the Natives, the argument is somewhat more complex. At first glance, this observation almost reads like a vacuum domicilium argument. The Natives ("offspring") are not able to properly use the land; consequently, the land is nothing more than a "tomb," although a glorious one. At closer inspection, however, the argument turns out to be far more intricate. The key to fully grasp Morton's idea is the word "enjoy." The Natives cannot "enjoy" their land because they lack "art" and "industry," both of which, according to Morton, are concepts of civilized cultures. Morton repeatedly mentions that the Indians are uncivilized but that they might be brought to civility in the near future (Morton 28, 36). Conversely, Morton paints a much darker picture of the Puritans by maintaining that they not only lack civility, but also humanity (Morton 113, 128, 147, 148). In this regard, the concept of "art" becomes especially meaningful. Morton's "[e]nigmattically composed" poems (135-6) should not only mock the Puritans, but also show their lack of art. ${ }^{11}$ To make this lack even more visible to the reader, Morton provides him with an explanation of the poem (139-40). Simultaneously, the Indians do not completely lack "art," for they join the revels at Ma-re Mount, which in itself might be seen as a performative art event. Moreover, Morton speculates that the Indians might "have had some literature amongst them" at some earlier point in time (16).

11 As Greenblatt has pointed out, most European colonizers "saw writing as a decisive mark of superiority" (10). Usually, this argument was employed with regard to native populations. Morton, however, by denying the Puritans literary knowledge and depicting the Indians as "protoliterate" (Cohen 6), turns around this argument. He uses the symbolic power of writing not to subjugate the Natives but to overpower a fellow European contestant. 
All in all, a presumably anti-Indian argument is turned around and transformed into a display of Indian rationality.

The last important aspect of "The Author's Prologue" is its deliberate via media rhetoric. The speaker of the poem describes the land "as if the elements had here / Been reconciled" (Morton 7). The emphasis on reconciliation is a clear product of Morton's Elizabethan background and a prominent feature in NEC. As Dempsey has noted, even the symbol on the front page with its merging male and female figures represents this ubiquitous attempt of reconciliation (Morton $7 \mathrm{n} 2$ ). Morton grants this specifically English quality to the Native Americans as well by maintaining that they are "not apt to quarrel one with another" (31). However, if a disagreement arises between two individuals it is tried to be "reconciled" (31) by all means possible, the last one being a duel between the two opponents. ${ }^{12}$ This wish for reconciliation is, according to Morton, not only to be found on the individual, but also on the political level. When there are disagreements between two "princes," one sends the other a "black wolf's skin [...] and the acceptance of such a present is an assurance of reconciliation between them" (75).

To summarize, the paratext of NEC lays the groundwork for the following three books. It establishes the communicative framework, shows first attempts to reverse colonial stereotypes, and introduces Morton's idea of reconciliation.

\subsubsection{Book $I$}

After these rich and complex introductory pieces, NEC's main part finally starts. Since the communicative framework of the work has already been clarified, one now has to ask oneself the question of genre. What sort of text is NEC? Unfortunately, there is no straight answer to that question. Instead, one must define each of the three books individually.

NEC's first book is best described as a "proto-ethnographic" (Burnham 407) account. The first chapter is primarily designed to present New England as the place most suitable for English colonization. Still, it also provides the basic principle for Morton's following observations on Indian life and New England's nature, a "principle of balance" (Connors, Morton 75) based once again on the via media. Numerous expressions such as "golden mean" (Morton 8, 9, 11, 12), "middle zone" (Morton 9), and the avoidance of "extremes" (Morton 8, 9, 11) sustain this argument. Today's readers might even feel tempted to attest Morton a modern concept of intercultural encounters; especially the term "middle zone" recalls contemporary notions of interculturality like "contact zone" (Pratt 1-11) or "middle ground" (White 50-93). Yet, such a perception of Morton would be as anachronistic as erroneous. Instead, as it has been shown in the genealogical analysis of this work, Morton's colonial gaze was heavily influenced by his upbringing and his

12 Dueling as a way to settle personal disputes and defending one's honor was also known in Britain. There, it was practiced up until 1843 (Cannon, "Duelling" 308). 
Alexander-Arthur Niedziolka

cultural roots. Consequently, his concept of interculturality might be best described as a humanist and proto-Enlightened one. Basically, Enlightened interculturality aims at overcoming cultural differences by emphasizing universal human traits (Sommer 295). By showing parallels between Old and New England, enlarging on them, and by repeatedly mentioning the Natives' humanity, Morton tries to achieve exactly this in Book I.

\subsubsection{Book II}

The second book of NEC is a detailed catalogue of New England's flora and fauna. The "Beauty of the Country," mentioned in the book's subtitle, is described in great detail and with very scenic vocabulary. Morton talks about "dainty fine rising hillocks, delicate fair plains [...] sweet crystal fountains and clear-running streams $[\ldots]$ making so sweet a murmuring noise to hear as would even lull the senses with delight asleep" (54). Notwithstanding this almost Romantic-sounding wallowing in nature's wonders, Morton's senses are wide awake. In the last sentence of the first chapter of Book II, he finally reveals his motives for showing his readers the country's "natural endowments" in such an exceedingly positive manner: he seeks to illustrate "what profitable use may be made of them by industry" (55). With this focus on profit it comes as no surprise that one finds a constant reiteration of the land's richness throughout Book II. This aspect becomes visible in Morton's almost inflationary use of the word "abundance" (Morton 54, 56, 57, $59,60,61,62,63,70,71,79,81,85,86,94)$. To dismiss allegations of lacking credibility, Morton constantly emphasizes that he has actually "seen" everything he talks about $(63,65,68,84,85,87,88)$. This stress on personal sensual experience clearly echoes the writings of Smith, Harriot, Brereton, and Rosier.

After observing the land's natural resources, Morton always tries to evaluate them using two main strategies. First, he often compares things in the New World to things in the Old World and, simultaneously, states the superiority of the New World commodities. Morton expresses this superiority by a constant use of the comparative degree: things in the New World are "better" (70), "sweeter" $(64,71)$, "finer" (60), or "bigger" $(62,63,70)$ than in England. This strategy, which was quite conventional in early colonial writing and was also used by Brereton, mainly aims at familiarizing the unfamiliar (via the constant comparisons to Old England) and at arousing further colonial interest in New England (by maintaining its economic benefits). The latter aspect also plays a major role in Morton's second evaluation strategy. Frequently, he illustrates how Native Americans use certain commodities $(58-9,70,71,73,74,75,81,86,87)$. The reader learns what value they attach to specific goods, a knowledge that might help him with future trading. Still, this strategy does not only have an economic dimension, for it also portrays the Natives as highly experienced users of the land and its resources. Thus, they are put in the position of potential role models for future English colonizers. 
An analysis of the last chapter of Book II (94-8) shows that an intensified colonization was Morton's major reason for composing it. Here, he develops the idea of a "Metropolis of New Canaan" (95), situated at "Lake Erocoise" (94). ${ }^{13}$ Morton elaborates on the strategic advantages of the lake, dreams of "very many brave Towns and Cities [...] which may have intercourse one with another by water" (95) and even hints at "the ever-elusive Northwest Passage" (Heath 164). "New Canaan's Genius," the poem that serves as epilog to Book II, then summarizes Morton's central aims of colonization. The text's genre is already a lucid hint at its importance. Morton places it immediately after the last prose paragraph of Book II, in which he calls for immediate colonization of the Erocoise region, for otherwise the Dutch would anticipate the English (98). Since Morton uses a poem to present his summary argument, it becomes clear that he attributed "considerable heuristic power" (Read 88) to poetry. The second stanza sums up the central aspects of Morton's colonial vision:

See what multitudes of fish

She presents to fit thy dish:

If rich furs thou dost adore,

And of Beaver Fleeces, store,

See the Lake where they abound,

And what pleasures else are found. (Morton 99)

One instantly notes the use of the female pronoun "[s]he" to refer to the lake, which constitutes a direct appeal to the masculinity of potential colonizers. Moreover, Morton's major colonial aims "pleasure and profit" (94) become visible. "[M]ultitudes of fish," "rich furs" and "Beaver Fleeces," according to Morton "the best merchantable commodity that can be found" (73), all promise a lot of "profit." Besides, Morton does not forget to mention the "pleasures." By doing so, he specifies his prior concept of "art" and "industry." Whereas in Smith constant hard work is needed to enjoy the land, Morton offers a somewhat less workintensive perspective. Since the land "abound[s]" with profitable commodities, only a little work is needed in order to make profit. Michelle Burnham even goes a step further and calls Morton's program an "economics of laborless abundance" (414). Yet, this notion is not entirely tenable. In fact, Morton does something rather remarkable: he questions his own cultural conceptions of wealth. He ponders: "[S]ince it is but food and raiment that men that live needeth (though not all alike), why should not the Natives of New England be said to live richly, having no want of either?" (49). He describes Native American economy as marked by subsistence. Things that are needed "by necessity" are then obtained "with industry" (50). Again, the Indians and in particular their economic ideas serve as guidelines for future English settlers. Morton summarizes that food and clothing, for

13 As Heath has pointed out, Morton is possibly referring to Lake Champlain, Lake Ontario, or the Saint Lawrence River (164). 
him the two central human needs, will be provided "with a little industry $[\ldots]$ in a very comfortable measure, without overmuch carking" (48). Hence, Morton was one of the very few authors of his time to notice that Native American economy was not based on the "accumulation of capital," a misconception even held by Locke (Cronon 79-80).

To summarize, Book II of NEC presents the core ideas of Morton's economic program for New England. The reader is provided with useful information about diverse trading goods, the Indians are portrayed as economic role models, and Morton makes an urgent call for an intensified English colonization of New England. If one tries to combine the ideas of the first and the second book regarding the Indians, one can support Murphy's characterization of Morton as "a sincere advocate of the importance of Indians to England's success in the New World" (768).

\subsubsection{Book III}

In direct opposition to the predominantly factual tone of Book II, NEC's third book is a firework display of narrative perspectives, intertextual allusions, irony and humor. It is the best known of the three books, for it offers a historical view different from the Puritan one. ${ }^{14}$ Still, it will be tried to show that it is much more than just a historical countertext.

The third book is the longest of NEC and has the size of books one and two combined. The text is interrupted by six poems and one song. The size of the book, Morton's reliance on poetic insertions, and the prominent placement at the end of NEC show that it was the most important one for Morton.

With regard to the narrative conception of Book III, two things are remarkable. First, there is a shift from a homodiegetic to a heterodiegetic narrative situation. Throughout the entire third book, the narrator Morton refers to the character Morton by using the third person singular. Such a striking change immediately signals an elevated literary character of the passage in question. Consequently, the reader, or at least Morton's implied reader, knows he has to change his reading strategy for Book III. Second, Morton introduces an Indian speaker, which constitutes "one of the very earliest attempts by Europeans to catch the metaphors and rhythms of Indian oratory" (Drinnon 397). After some of the Plymouth Puritans have "defaced the monument of the dead at Passonagessit" (Morton 106), the Neponset sachem Chikatawbak delivers a speech to his followers. As Major has observed, this speech is "certainly distinct from Morton's normal style and indicates some feeling for Indian mannerisms" (qtd. in Morton 106n335). On the level of content, it describes a nightly vision of the Neponset chief in which a spirit calls him to take action against the Puritans. Morton's "feeling" for the Native American mind shows itself in the insightful treatment of nature and spirituality.

14 On Morton's value as a historiographical source see Ordahl Kuppermann. 
The beginning of the speech exemplifies this: "When last the glorious light of all the sky was underneath this globe, and birds grew silent, I began to settle (as my custom is) to take repose" (Morton 106). Morton seems to have understood the intimate relations of the Natives' collective and individual lifestyles with nature. The choice of the adjective "glorious" suggests a profound reverence for light on the Indian side. In addition, light is the decisive factor in the sachem's daily life, for it directly influences his "custom[s]". Interestingly enough, Morton himself uses light as a guiding principle in another place of NEC. When he maintains that the Native Americans lead a "contented life," he bases his notion upon "human reason, guided only by the light of nature" (50). Once again, although in an indirect fashion, the Indians are portrayed as reasonable beings. Following the initial depiction of nature, the sachem closes his eyes and glides from the natural into the spiritual world. This transition is emphasized by yet another change of speakers, for now the spirit itself starts talking. This enormous narrative distance allows for a direct attack on the Puritans: the spirit calls them "wild people," an "ignoble race," and a "theevish people" (107). The mentioning of "wild people" echoes F.C.'s dedicatory poem, in particular the reversal of the wild-civilized dichotomy. This time, however, the reader is not confronted with a second-hand account of an English armiger, but with a first-hand relation of the Puritans' incivility by an Indian speaker. Moreover, the careful structuring and high register of the passage clearly underlines Morton's idea of Native American civility or, at least, potential for civility.

Besides these narratological questions, a reflection on the genre of Book III is equally important for an understanding of the same. It has been noted by different critics that Morton was almost the only colonial author to employ humor and irony in his writings (Jehlen 93; Galinsky 26-34). But does that make the third book of NEC really a "satire" (Franklin, Discoverers 186) or a "mock epic" (Seelye 176)? Both classifications are highly unlikely and do not meet the book's literary and communicative complexity. Rather, NEC's third book might be considered the literary version of an English court masque. ${ }^{15}$ The masque genre was at its height during the reigns of James I and Charles I, with an "allegorical or mythological plot symbolizing the monarch's political power and wealth" (Cross 627). During this period, a typical masque contained the following elements: "a poetic induction or prologue," "antimasque(s)," "main masque," "revels," "epilogue," and "costuming" (Hull/Pearson/Sadlack). A scrutiny of NEC's third book reveals that it includes all important parts. Besides their individual characters and functions, Books I and II might be read as an extended prologue to Book III. They prepare the stage by introducing Morton's most important topics: Native Americans, the beauty and richness of New England, how the land is used by the Indi-

15 Shea (58) and Burnham (409) have discussed NEC in its entirety as a masque. Yet, keeping in mind the styles and individual functions of the first two books, this argument seems too generalized. Hence, the term masque will only be used with regard to Book III in this work. 
ans, and how future English settlers might utilize the land. The ironic portrayals of the Puritans can be seen as antimasques, for they constitute highly "grotesque and comic scenes" (Cross 627). Moreover, the Puritans' misuse of the land and their moral misbehavior "act as foils to the main masque" (Hull/Pearson/Sadlack). This allows Morton to portray himself, other Englishmen, and Native Americans as positive characters. The main masque, then, is the depiction of New England's riches. As Shea has observed, Morton tried to write "New England as masque" (58; Shea's italics). Thus, Morton's masque does something rather extraordinary: on the one hand, it celebrates the present richness of the land; on the other hand, by giving examples on how to properly use and colonize the land, it celebrates potential future "power and wealth" for the monarch. The revels are explicitly described by Morton and even referred to as "Revels" (134-41). Although there is no designated epilogue to NEC, the entire last chapter (196-99) might be read as a summary statement. Here, Morton repeatedly asks the Puritans to "repent" (198, 199) their inhumane behavior and misuse of the land. The last important feature, costuming, is represented by Morton's naming strategies. He deliberately disguises himself as "Mine Host" throughout the entire third book (124, 135, 141-8, 155-7). The same strategy is employed with regard to the Puritans: William Bradford is presented as "Minos," William Brewster as "Radamant," Samuel Fuller as "Eacus" (Morton 152), Miles Standish as "Captain Shrimp" (Morton 143), and John Winthrop as "Joshua Temperwell" (Morton 169).

Still, not only these internal clues suggest a reading of book three as a masque. Especially Morton's Inns of Court education makes an influence of the masque genre highly likely. Dempsey has noted that NEC "is very much constructed out of all the Inns could teach" (Morton 49). Hence, Morton's cultural formation at the Inns of Court was at least as important for his writing as the legal training he received there. Furthermore, Morton probably took part in one of the most important cultural events ever to take place at the Inns, the Gesta Grayorum of 1594. This Christmas celebration in honor of Elizabeth I included speeches, lyrical recitations, plays, and a masque (Dempsey, Morton 52). It looks as if Morton has learned two valuable lessons from this event: the appreciation of a certain "pastoral idealism" (Dempsey, Morton 53) and the importance of ritual for the consolidation of a community. The pastoral idealism is most visible in Morton's descriptions of New England as "Nature's Masterpiece" (54) and his perception of the Natives, who, according to Morton, "live a contented life" (48). The ritualistic ending performances of the Gesta Grayorum also had a lasting influence on Morton. First, some songs were sung, then a maypole was raised, and finally all participants performed "fertility-related" dances around the maypole (Dempsey, Morton 55). The parallels to Morton's own New England revels, celebrated 33 years later, are more than obvious. Morton noticed the applicability of ritualistic modes like dance or song 
so as to produce communal cohesion and to facilitate political relations. ${ }^{16}$ These ideas were certainly still with him when he read the first published English travel accounts about the New World. As it has already been illustrated, these accounts showed the attentive reader the importance of ritual for successful Indian-English relations. Thus, in order to meet the demands of the New World, Morton simply combined the notions of his Elizabethan education with the Indians' wish for "entertainment to accompany any business transaction" (Heath 150).

To summarize, Book III is not only Morton's charge against the Puritans, but also a witty summary of English colonial presence in New England. To read it only as an anti-Puritan attack would ignore a lot of its complex literary character. Moreover, it seems unlikely that a well-trained lawyer like Morton would run the risk of rendering his indictment less effective by the constant use of figurative language and intertextual allusions. Consequently, Book III can be seen as Morton's definitive statement about New England, its history, its present condition, and its future possibilities.

\subsection{Paralleling Indian and English Traditions}

Up until now, the basic features of Morton's Indian discourse have been established. In this part, the most striking aspect of these will be analyzed, the parallels Morton draws between Indian and English culture. It has already been illustrated that there were some undeniable similarities between both cultural spheres. A careful reading of $N E C$ shows that Morton was aware of them and consciously integrated them into his discourses. In fact, the elaboration on these parallels constitutes the most important part of Morton's Indian discourse, for it formed the basis for a unique strategy of appropriation.

\subsubsection{Law and Justice}

Being a trained lawyer, Morton put high emphasis on English law and its careful observance, even in the colonies. Thus, when Morton is asked by the Puritans to sign several articles which should establish the Bible as the only guiding principle for religious and political questions, he refuses (Morton 165). He insists on the following amendment: "So as nothing be done contrary or repugnant to the Laws of the Kingdom of England' (Morton 165; Morton's italics). For Morton, the existence of a fixed set of laws is a prerequisite for a humane and civilized society. As a result, he criticizes the Puritans in a twofold manner. First, because they "take the Law in their own hands," even though they are "natural-born [English] Subjects" (Morton 147). Second, Morton perceives Puritan jurisdiction as unfair and arbitrary.

16 The use for "political purposes and 'diplomatic occasions" was a genuine feature of Ben Jonson's masques (Hull/Pearson/Sadlack). Since several critics have observed that Jonson was a formative influence on Morton (Read 83, Shea 57), Morton certainly attributed substantial political power to the masque. 
When a certain "Mr. Innocence Fairecloath" (Morton 177) arrives at the colonies and lends money to some of the Massachusetts Bay Puritans, they take legal action against him in order not to repay their debts. Morton criticizes the subsequent trial because "no defense would serve his [Fairecloath's] turn, yet was there none to be seen to accuse him save the Court alone" (Morton 178). Next, Morton describes the severe and disproportionate punishment Fairecloath receives. The reason for this unusually cruel judgment is, according to Morton, that Fairecloath is "a member of the Church of England, and therefore (in their account) an enemy to their Church and state" (177). In brief, Morton criticizes the abuse of jurisdiction for political ends.

The way Morton depicts the Indian legal system stands in stark contrast to the Puritan one and thus is much closer to his own notions of a fair jurisdiction. Morton maintains that there are only two capital crimes in Native American societies, lying and stealing (43). In the eleventh chapter of Book III-a chapter remarkable in many ways-he depicts how a neighboring Wampanoag tribe deals with theft. Morton, who refers to himself in this chapter as the "owner of Passonagessit" (125), leaves his plantation in winter. During his absence, some Indians, "accustomed to buy food" (125) from him, come to Ma-re Mount in order to trade. Since Morton is absent, they simply take some of his corn, but leave "enough behind" (125). When the Wampanoag sachem is informed about this incident, he immediately sends ten beaver skins as compensation and Morton accepts. Later, Morton depicts a similar scene, in which the Puritans sequestrate "all his corn, with some other of his goods" (168). Morton does not receive any recompense and criticizes that this behavior is "contrary to the laws of hospitality" (168), laws Morton certainly has learned in England and which were essential for his world view and notions of communalism (Dempsey, Morton 20). The Native Americans, conversely, seem to share Morton's love for hospitality and fairness. The sachem takes responsibility for the deeds of his followers and tries to maintain harmonious relations with Morton. Again, this proceeding is clearly based on reciprocity: a negative action like theft is immediately balanced with a positive reaction.

All in all, the Indians in NEC deal with legal questions in a way similar to Morton, for all their decisions are based on fairness and respect. This leads Morton to summarize the Indians" treatment of law and justice thus: "[T]he uncivilized people are more just than the civilized" (126).

\subsubsection{Politics and Economy}

Just like most other English voyagers, Morton had a primarily economic interest in the New World. His dream of a trading metropolis near "Lake Erocoise" has already been illustrated. However, Morton was one of the first colonial authors to note that the Indians also had a heightened political and economic interest in the settlers. 
Already in the second chapter of Book I, Morton talks about the Natives' "coveteous desire [...] to commerce" with the English (17). Simultaneously, Morton states that the English share this desire (17). Thus, a reciprocal wish for colonial and transatlantic commerce is established very early in NEC. Yet, before Morton can elaborate on this notion, he has to persuade his readership that the Indians are actually capable of trading in a way acceptable to the English. Consequently, Morton acknowledges that there is "Commerce and Trade" (24) between the different Indian tribes and later even dedicates an entire chapter to further display how exactly this trade works (34-6). He introduces the Native Americans' monetary system based upon "Wampampeak" (34) and alludes to their wish for "novelt[ies]" (35). This depiction implicitly seeks to render Native American economy compatible with English economy by stating that it is also based on money and a system of supply and demand. In one aspect, Indian economy is even superior to the English, for it has not been corrupted by a desire for "pomp" (Morton 50). This leads Morton to argue that the Indians live in a manner closely resembling "Plato's Commonwealth" (49).

Here, Morton's discourse seems contradictory: If the Indians live in an almost ideal society and are not interested in superfluous commodities, why should they be interested in trading with the English? Morton provides a twofold answer to this dilemma. On the one hand, the Indians are "very ingenious [...] and very subtle" (Morton 37). This intelligence, as indicated by Morton, will lead them to accept the superiority of an already civilized nation like the English. In this context, Morton mentions the introduction of salt as a means to "bring them to civility" (36) and make them permanent trading partners. On the other hand, Morton's idea that the Indians "love" (8) the English helps to overcome this contradiction. Thus, the rational argument about the Indians' intelligence is complemented by a highly emotional line of reasoning.

Closely related to the economic program is the political one. On the English side, it is clear that colonizing the New World was an important economic undertaking which should open up new markets and provide urgently required resources. However, it also meant a huge expansion of political influence and power. Again, Morton was one of the first to note that Native Americans shared the wish to extend their political power and that they consciously used the colonial situation to achieve this aim. In the very tellingly entitled chapter "Of Their Subtlety" (37-40), Morton describes how Neponset sachem Chickatawbak makes use of his loose connection with the English to trick the militarily superior Narragansetts into retreat. The depiction of Native Americans as political power players is also exemplified in the beginning of Book III (Morton 103-5). Here, an anonymous sachem establishes diplomatic ties with the English. Shortly afterwards, he asks the English to "let out the plague and destroy" (Morton 104) a rivaling sachem and his tribe. 
To summarize, Morton tries to portray New England Indians as economically and politically comparable to the English. In his view, both peoples desire to enlarge their spheres of influence in the two areas; thus, an important prerequisite for successful trade and political relations between both cultures is established.

\subsubsection{Religion}

The question of Indian religion has already been partly discussed in one of the preceding paragraphs. However, Morton elaborates much more on the ostensible parallels between English and Indian religion.

Morton's early and unusually undifferentiated remark that "the Natives of New England have no worship nor [sic] religion at all" (Morton 24) overshadows the entire rest of NEC. Yet, later in his work, Morton concedes several important religious characteristics to the Natives. He acknowledges that they have a history of creation, that they accept the immortality of the soul, and that they bury their dead (Morton 42-3). Especially Morton's portrayal of the two former aspects shows clear parallels to (English) Christianity. The Indian history of creation reported by Morton talks about a god making "one man and one woman" (42). These first two human beings procreated and lived in a carefree manner. This angered the Indian god and he decided to drown the "greatest part of them that were naughty men" (Morton 42). The parallels to the Christian history of creation are obvious: a man and a woman in the beginning, a paradisiacal life, the Fall, and God's subsequent punishment. In fact, the Indian narrative parallels the Christian one in such a manner that Morton at one point even calls the Indian god "Lord" (Morton 42).

Besides establishing such general similarities to Christianity, Morton specifically tries to parallel Anglican and Native American religion. When he talks about Indian afterlife, he states: "The other [...] increased the world; and when they died (because they were good) went to the house of Kytan" (42). Here, Morton insinuates that New England Indians, just like the Anglicans, believe in a system of good works. Only those that are "good" go to Kytan; those that are "naughty" go to "Sanaconquam," who lives in the earth and "feeds upon" the dead (Morton 42). Hence, Indians and Anglicans have a shared path to redemption. Needless to say, the Puritans, who did not believe in good works, are excluded from this union.

All these formal religious similarities are designed to support one of Morton's major aims, namely Christianizing the Natives. According to Morton, this would help the Indians to not only lead a "contented," but a truly "happy" life (48). Still, Morton is not primarily interested in the Natives' personal happiness; rather, a comprehensive Christianization of New England would strengthen the social and economic ties between Native Americans and the English.

After having established the formal resemblances of both religions, Morton tries to depict the Natives as actually being capable of becoming good Christians, primarily by highlighting their humanity $(14,22,113,129,148)$. If one looks at 
Morton's critique of Puritan religion, one notes that his most salient objection is its lack of humanity: "[T] hey [the Puritans] had learned to work all to their own ends, and make a great show of religion, but no humanity" (Morton 147). Conversely, this means that the Indians may not possess an acceptable form of religion yet, but at least they provide the necessary requirements. In a second step, Morton shows that the Indians are already instruments of the Christian God. When the Plymouth group banishes Morton and burns his house, a group of Indians approaches the scene. Morton describes their reaction thus:

[A]nd [the Indians] did reprove these Eliphants of Witt for their inhumane deed. The Lord above did open their mouths like Balaam's Ass, and made them speak in his behalf sentences of unexpected divinity, besides morality; and told them that God would not love them that burned this good man's house. (171)

This incident is highly remarkable, for here Native Americans criticize the doings of the Puritans on a religious basis. According to the Indians, this deed is wrong because it is "inhumane" and against the will of God. This exceptionally moral behavior from a group of Native Americans was even for an Indian-friendly man like Morton too much to bear. Thus, his strategy of portraying the Indians as God's instruments is also a strategy of self-protection. Such a moral superiority without having an established Christian church would have seriously damaged Morton's religious world view.

\subsubsection{Genealogy}

By far, the most outstanding feature of Morton's Indian discourse is his idea of a common Indian-English ancestry. In order to illustrate this notion, Morton draws on a well-known and extremely popular English founding myth, the myth of Brutus the Trojan. According to this narrative, Brutus, a descendant of Aeneas, came to Britain, conquered the land, gave it its name, and founded London (Cannon, "Brutus" 134). This legend had been preserved in numerous literary works, among them Geoffrey of Monmouth's influential Historia Regum Britanniae, and was readily embraced by Tudor historians (Cannon, "Brutus" 134). Thus, it still played a vital role when Morton was being born and educated.

In NEC, Morton tries to integrate Native Americans into Britain's founding history. He argues that after Brutus's departure from Troy, he and his followers "were dispersed" and that several persons possibly got lost at sea (Morton 17). According to Morton, it is highly probable that some of these lost people arrived at the New World and, consequently, are the ancestors of the Native Americans. To strengthen his argument, Morton cites various linguistic observations. He asserts that the New England Indians "use very many words both of Greek and Latin, to the same signification that the Latins and Greeks have done" (Morton 14). The fact that Morton places these interpretations right in the beginning of his 
book shows that the common genealogy played a major role in his argument. Hence, it comes as no surprise that he continues to pass on "classical authority" to the Natives throughout NEC (Jehlen 94). The already mentioned emphasis on Indian humanity and the reference to "Plato's Commonwealth" can be seen in this context as well.

The strategy of conveying classical authority to the Native Americans is best exemplified in the imagery of the poem "Carmen Elegiacum" (Morton 132-3). Written for the "Barren Doe of Virginia," it employs a plethora of classical allusions. However, one suddenly finds the following lines: "A great Squa Sachem, she can point to go / Before grim Minos" (Morton 132). In just two lines of verse, two temporarily and culturally different spheres are yoked together: the colonial present, here represented by the "Barren Doe," an Englishwoman tellingly portrayed as a "great Squa Sachem," and the classical past, embodied in the figure of Minos, "king of Crete's 'Labyrinth' and, later, a 'judge of the dead' in the Underworld" (Morton 132n439).

All things considered, "Carmen Elegiacum" and the general outline of Book III typify Morton's most important discursive strategy with regard to the Indians. By describing the New World and its inhabitants through the use of classical allusions and traditional English forms, Morton writes the Indians into England's cultural canon.

\section{Morton's Indian Discourse and Its Implications for America}

Having discussed the genealogical and critical parts of the present discourse analysis, one last problem remains: Why does Morton talk about the Indians the way he does?

Up until now, few critics have tried to answer that question. Jehlen considers Morton's treatment of Indian discourse, especially the strong emphasis on a common genealogy, a direct attack on the Puritans because "it demoted [them] from the first rank of heirs of an ancient legitimacy by claiming for England (and its deputy-cavaliers like Morton) descent from the yet more ancient Troy" (95). Canup argues that Morton's depiction of the Indian-English encounter "as a long delayed family reunion" aimed at damaging the Puritans' wish for exceptionalism (123).

Both views have obviously accepted Puritan superiority in early American history and judge the Indian discourse in NEC accordingly. Still, Jehlen and Canup, like most other critics, have failed to observe that Morton is not entirely antiPuritan, that he does not want to make the Puritans "exiles in their own kingdom" (Shea 58). To a certain degree, Morton even appreciates Puritan settlement in New England. He writes: 
Howsoever, they [the Puritans] have deserved (in mine opinion) some commendations, in that they have furnished the country so commodiously in so short a time, although it hath been but for their own profit. Yet posterity will taste the sweetness of it, and that very suddenly. (Morton 55)

Furthermore, directly attacking New England Puritans would not have been in agreement with Morton's omnipresent via media background. If one tries to understand the implications of his Indian discourse from this perspective, a whole new picture emerges. It is the idea of a colonial society consisting of Native Americans, Englishmen like Morton, and Puritans, all united by a common origin and, at least in the case of Indians and Englishmen, similar cultural notions and values. To put it bluntly, one could even borrow Canup's words and call the entire colonial encounter a "family reunion" (123).

Yet, this notion of "a community that integrates native-born and Europeanborn" (Bumas 3) is not the mere product of humanist thinking, but is designed as a means to facilitate present and future Indian-English relations. Morton's use of ritual to consolidate colonial society has already been hinted at and has thus been discussed by several critics (Heath 150-1, Zuckerman 273). Still, Morton goes a lot further. A closer look at his May Day revels, especially at the "Rise Oedipus" poem and "The Song," perspicuously reveals his Native American and New England agendas. ${ }^{17}$

The most outstanding feature of "Rise Oedipus" is Morton's depiction of America as a "widow" (139), according to Dempsey "an almost singular metaphor in colonial texts" ("Riddle" 295). He does not explicitly mention the word "widow" in the poem, but in the following explanations. In the poem itself, he uses two female figures to refer to America, "Scilla" and "Niobe" (135-6). Scilla is used throughout the entire poem; only in the beginning Morton tells his readers that she sits "in forme of Niobe" (135). The reference to Niobe, whose children God killed for her pride (Dempsey, "Glossary" 204), together with the assertion that Scilla is "solitary" (135) and "unfortunate" (136), establish the picture of a sad, abandoned woman. Later in the poem, the reader gets to know that a lack of "virtue masculine" (136) is the reason for Scilla's dolor. She once had a husband, namely the Indians, that was able to satisfy her demands. Moreover, it is insinuated that the current manly presence in New England, i.e. the Puritans, is not able to please her in any way. All in all, Morton changes the omnipresent stereotypical concept of America as a "virgin" and portrays the land as a grown-up, sexually experienced female figure. This transformation of a dominant colonial metaphor also produces a new appellative dimension. Whereas former colonizers like Ra-

17 The following observations are indebted to the excellent close readings of "Rise Oedipus" by Arner, Murphy, and Dempsey ("Riddle"). All three have helped to untangle the dense imagery and cornucopia of classical figures and thus made this highly complex poem understandable for modern day readers. 
leigh used the "virgin" metaphor as an appeal to masculinity and a request for raping the land, Morton uses the "widow" metaphor to call for a more responsible and caring masculine presence in New England.

The subsequent "Song" (137-8) and the raising of a maypole might be seen as Morton's attempt to answer this call for a new "husband." The sexual character of "Rise Oedipus" is taken up again in "The Song." The celebration of "Hymen" and the often quoted invitation to the "Lasses in beaver coats" to accompany Morton's colonists "night and day" clearly go in this direction (Morton 137-8). However, the strong sexual rhetoric is not an expression of transient lasciviousness, but part of Morton's "formula for successful colonizing" (Dempsey, "Riddle" 283). On the one hand, given the fact that in all regions of English settlement there were more men than women (D'Emilio/Freedman 9), it can be seen as sexual realpolitik, as a way to pragmatically enhance the demographic situation in the colonies. In this context, Morton's earlier statement that children are the greatest "of all riches" (120) gets a whole new meaning as well. On the other hand, this formula would have had important social and economic consequences. It is true that Morton and "most English settlers had a conservative vision: the reestablishment of traditional patterns of family and community in the colonies" (D’Emilio/Freedman 6). Still, intermarriage and the resultant racial intermixture would have also helped to reconcile America's old and new "husband" and brought about a society that combined the Indians' expertise in using the land with the benefits of English civilization. ${ }^{18}$ Without doubt, such a skilled society would have been able to satisfy the grieving "widow" America and could have strengthened the ties between Old and New England.

However, two immediate problems remain: who is in power in this intermixture of Native Americans and English settlers and who owns the land? Morton's concept for the encounter of two nations is unambiguously stated: "one must rule, and the other be ruled, before a peace can be hoped for" (113). Morton never clearly states which nation should rule in New England; yet, there is one detail in NEC that renders an English supremacy likely. The Indian mass mortality has created a power vacuum, which makes the land "more fit" (Morton 20) for English colonization. In Morton's view, the few remaining Indians cannot refill this void and the Puritans lack the intimate understanding necessary for a successful role as America's new "husband." Consequently, only Englishmen like Morton have a legal claim on the land and on governing its inhabitants. This scheme of appropriation is fairly remarkable. Unlike most of his contemporaries, Morton neither uses vacuum domicilium rhetoric to support his claim, nor does he draw on religious or racist arguments. Instead, his idea of appropriation is the logical continuation of his Indian discourse: since the main owner of the land is dead, it now belongs to the closest "family member," the English. This strategy has far-

18 Bumas argues that the question of racial intermixture was in fact the most important point of conflict between Morton and the Puritans (5). 
reaching consequences for the colonization of America. First, Morton cleverly excludes other foreign colonial powers like France and the Netherlands. Second, he renders the colonization of New England a continuation of English history. Third, he gives the whole process of appropriation a semblance of legitimacy.

All things considered, it looks as if this strategy of appropriation was the main reason for Morton's unique Indian discourse. His detailed attempt to portray Indians and English as descendants of the same culture, sharing numerous social and cultural values, should support the legal claim on the land. Thus, Morton hoped for extensive English colonization in New England, but without unnecessary coercion or suppression. Rather, he envisioned a model of colonization that was based on a twofold concept of "love." With regard to the past and present, it was seen as family love and used so as to justify English appropriation of New England. With regard to the future, it referred to physical love between Indians and the English. Intermarriage and procreation should generate a powerful colonial society and further strengthen the bonds between Old and New England.

\section{Conclusion}

From a European perspective, the discovery of America really was the discovery of a "wild exteriority," the unearthing of a discursive tabula rasa. Hence, the subsequent attempt of colonization can be considered a European competition for imposing conflicting discourses on the New World. Among these, the opposing Indian discourses certainly produced most of the problems which arose during the colonial period. In this work, it has been tried to show that Thomas Morton provided a highly unique Indian discourse, for he not only based it on his English $a$ priori assumptions but also integrated parts of the Indians' discursive policing into it. The result was a discourse that paralleled Indian and English cultures, indeed portrayed both peoples as related by ties of kindred. This allowed for a strategy of appropriation that heavily relied on the concepts of family and love. Unfortunately, Morton was not aware that at the time of his arrival New England had already ceased to be a discursive exteriority and was being influenced by Puritan ideas. As a result, NEC really became an unsuccessful "knowledge project" (Read 6) during the consolidation of a colonial New England society; however, it is a project worth remembering, not only for its quality as a countertext to Puritandominated historiography but also for its attempt to provide an ideological basis for colonization that sought to integrate all parties in a non-violent manner. Moreover, it showed that an individual could respect his cultural roots without demoting the cultural other. Morton was certainly no altruistic philanthropist and most of his actions aimed at advancing the state of his home country. Yet, due to his heart-felt affection for the New World and its inhabitants, he tried to find a compromise, a via media that allowed for a peaceful colonization and an equitable use of the land. Overall, John Seelye succinctly summarized Morton's character 
and ideas: "Morton was what was not wanted in the Puritan utopia, yet for all that, indeed, perhaps because of it, he is very much in the American grain, albeit cut from English oak." (165) Without a doubt, the fact that a complex and challenging book like NEC, the literary legacy of a historical underdog, is still read today shows that Morton's ideas have touched certain feelings which are deeply rooted in American culture. 


\section{Works Cited}

Adams, Charles Francis. "Thomas Morton of Merry-Mount." Introduction. The New English Canaan. By Thomas Morton. Ed. Charles Francis Adams. Boston: Prince Society, 1883. 1-98.

Andrews, Kenneth R. “The Sea-War with Spain, 1585-1603.” Marvel 193-212.

Arner, Robert D. "Mythology and the Maypole of Merrymount: Some Notes on Thomas Morton's 'Rise Oedipus..” Early American Literature 6 (1971): 156-64.

Barbour, Philip L., ed. The Complete Works of Captain John Smith (1580-1631). Chapel Hill: U of North Carolina P, 1986. 3 vols.

Boyer, Paul S., et al. The Enduring Vision: A History of the American People. 5th ed. Boston: Houghton, 2004.

Bragdon, Kathleen. "Narragansett." Hoxie 417-8.

—. Native People of Southern New England, 1500-1650. Norman: U of Oklahoma P, 1996.

Brereton, John. A Briefe and True Relation of the Discoverie of the North Part of Virginia. 1602. Burrage 325-40.

Bumas, E. Shaskan. “'The Forgotten Art of Gayety': Masquerade, Utopia, and the Complexion of Empire." Arizona Quarterly 59:4 (2003): 1-30.

Burnham, Michelle. 'Land, Labor, and Colonial Economics in Thomas Morton's New English Canaan.” Early American Literature 41.3 (2006): 405-28.

Burrage, Henry S., ed. Early English and French Voyages: Chiefly from Hakluyt 15341608. 1906. New York: Barnes, 1959.

Cannon, John. "Brutus.” Cannon, Oxford 134.

_. "Duelling." Cannon, Oxford 308.

_. "Elizabeth I." Cannon, Oxford 339-41.

— - ed. The Oxford Companion to British History. 1997. Rev. ed. Oxford: Oxford UP, 2002.

Canup, John. Out of the Wilderness: The Emergence of an American Identity in Colonial New England. Middletown: Wesleyan UP, 1990.

Cohen, Matt. "Morton's Maypole and the Indians: Publishing in Early New England." Book History 5 (2002): 1-18.

Connors, Donald F. Thomas Morton. New York: Twayne, 1969.

Cronon, William. Changes in the Land: Indians, Colonists, and the Ecology of New England. New York: Hill, 1983.

Cross, Eric. "Masques.” Cannon, Oxford 627. 
D’Emilio, John, and Estelle B. Freedman. Intimate Matters: A History of Sexuality in America. New York: Harper, 1988.

Dempsey, Jack. “Reading the Revels: A Glossary.” Morton 201-6.

—_. "Reading the Revels: The Riddle of May Day in New English Canaan." Early American Literature 34:3 (1999): 283-312.

- Thomas Morton of "Merrymount": The Life and Renaissance of an Early American Poet. Scituate: Digital Scanning, 2000.

Drinnon, Richard. "The Maypole of Merry Mount: Thomas Morton \& the Puritan Patriarchs." The Massachusetts Review 21 (1980): 382-410.

Foucault, Michel. "The Order of Discourse." Trans. Ian McLeod. Untying the Text: A Post-Structuralist Reader. Ed. and introd. Robert Young. Boston: Routledge, 1981. 48-78.

Franklin, Wayne. Discoverers, Explorers, Settlers: The Diligent Writers of Early America. Chicago: U of Chicago P, 1979.

—. "Literature to 1700." The Norton Anthology of American Literature. Ed. Nina Baym et al. 6th ed. Vol. A. New York: Norton, 2003. 3-16.

Galinsky, Hans. "History and the Colonial American Humorist: Thomas Morton and The Burwell Papers." Forms and Functions of History in American Literature: Essays in Honor of Ursula Brumm. Eds. Winfried Fluck, Jürgen Peper, and Willi Paul Adams. Berlin: Schmidt, 1981. 21-43.

Greenblatt, Stephen. Marvelous Possessions: The Wonder of the New World. 1991. Oxford: Clarendon P, 1992.

Harriot, Thomas. A Brief and True Report of the New Found Land of Virginia. 1588. Digitalcommons@UNL. Ed. Paul Royster. 2007. U of Nebraska at Lincoln. 29 July $2008<$ http://digitalcommons.unl.edu/cgi/viewcontent.cgi?article $=1020$ \&context $=$ etas $>$.

Heath, William. "Thomas Morton: From Merry Old England to New England." Journal of American Studies 41.1 (2007): 135-68.

Hoxie, Frederick E., ed. Encyclopedia of North American Indians. New York: Houghton, 1996.

Hull, Helen, Meg Pearson, and Erin Sadlack. "History of the Masque Genre." John Milton's A Maske or Comus. 2000. Maryland Institute for Technology in the Humanities. 20 Jul. 2008 <http://www.mith.umd.edu/comus/final/ceg enre.htm $>$.

"Infamy." The Oxford English Dictionary. 2nd ed. 1989.

Jehlen, Myra. "The Literature of Colonization." The Cambridge History of American Literature. Ed. Sacvan Bercovitch. Vol. 1. Cambridge: Cambridge UP, 1994. 11-168.

Lee, Stephen J. The Reign of Elizabeth I: 1558-1603. London: Routledge, 2007.

Lockyer, Roger. "Charles I.” Cannon, Oxford 189-90. 
—. "James IV." Cannon, Oxford 527-8.

Manning, Helen Vanderhoop. “Wampanoag.” Hoxie 661-2.

Manning, Roger B. "Elizabeth Unifies England by Establishing a National Church." Marvel 39-48.

Marvel, Laura, ed. Elizabethan England. San Diego: Greenhaven P, 2002.

Morgan, Kenneth O. The Oxford History of Britain. 1984. Oxford: Oxford UP, 2001.

Morton, Thomas. New English Canaan. 1637. Ed. Jack Dempsey. Scituate: Digital Scanning, 2000.

Murphy, Edith. "'A Rich Widow, Now to Be Tane Up or Laid Downe': Solving the Riddle of Thomas Morton's 'Rise Oedipus'." The William and Mary Quarterly 53.4 (1996): 755-68.

O'Gorman, Edmundo. The Invention of America: An Inquiry into the Nature of the New World and the Meaning of its History. Bloomington: Indiana UP, 1961.

Ordahl Kuppermann, Karen. “Thomas Morton, Historian.” New England Quarterly 50.4 (1977): 660-4.

Picard, Liza. Elizabeth's London: Everyday Life in Elizabethan London. London: Weidenfeld, 2003.

Pratt, Mary Louise. Imperial Eyes: Travel Writing and Transculturation. London: Routledge, 1992.

Pring, Martin. A Voyage Set Out From the Citie of Bristoll, 1603. 1625. Burrage 34152.

Raleigh, Walter. The Discovery of Guiana. 1595. Project Gutenberg. Ebook \#2272. 2006. 21 July $2008<$ http://www.gutenberg.org/files/2272/2272.txt>.

Read, David. New World, Known World: Shaping Knowledge in Early Anglo-American Writing. Columbia: U of Missouri P, 2005.

Rosier, James. A True Relation of the Voyage of Captaine George Waymouth, 1605. 1605. Burrage 353-94.

Salisbury, Neal. Manitou and Providence: Indians, Europeans, and the Making of New England, 1500-1643. New York: Oxford UP, 1982.

—. "The Indians' Old World: Native Americans and the Coming of Europeans." William and Mary Quarterly 53.3 (1996): 435-58.

Seelye, John. Prophetic Waters: The River in Early American Life and Literature. New York: Oxford UP, 1977.

Shea, Daniel B. "'Our Professed Old Adversary': Thomas Morton and the Naming of New England.” Early American Literature 23.1 (1988): 52-69.

Slotkin, Richard. Regeneration through Violence: The Mythology of the American Frontier, 1600-1860. 1973. Norman: U of Oklahoma P, 2000.

Smith, John. A Description of New England. 1616. Barbour 1: 291-370. 
- The Generall Historie of Virginia, New-England, and the Summer Isles. 1624. Barbour 2: 25-475.

Sommer, Roy. "Interkulturalität." Metəler Lexikon Literatur- und Kulturtheorie. 3rd ed. Ed. Ansgar Nünning. Stuttgart: Metzler, 2004. 295.

Viault, Birdsall S. English History. New York: McGraw, 1992.

White, Richard. The Middle Ground: Indians, Empires, and Republics in the Great Lakes Region, 1650-1815. Cambridge: Cambridge UP, 1991.

"Wild." The Oxford English Dictionary. 2nd ed. 1989.

Zuckerman, Michael. "Pilgrims in the Wilderness: Community, Modernity, and the Maypole at Merry Mount.” New England Quarterly 50.2 (1977): 255-77. 